\title{
Analisis Strategi Penguatan Usaha Kecil Menengah Pada Masa Pandemi Covid-19 di Kota Medan
}

\author{
Ngatno Sahputra*, Budi Antoro, Zulham \\ Universitas Dharmawangsa \\ *Correspondence email: ngatnosahputra@dharmawangsa.ac.id; budiantoro@dharmawangsa.ac.id; \\ zulham@dharmawangsa.ac.id
}

\begin{abstract}
Abstrak. Tidak dapat dipungkiri bahwa usaha mikro kecil menengah memiliki peran strategis dalam sistem ekonomi Negara, diantara peran strategis tersebut adalah menyerap sumber daya lokal dan lapangan kerja yang lebih luas serta berkontribusi dalam upaya pengentasan kemiskinan. Berdasarkan data Kementerian Koperasidan UKM Republik Indonesia tahun 2017 tenaga kerja yang terserap dari UMKM sebanyak 97,02\%. Angka ini meningkat dari tahun sebelumnya sebanyak 112.828 .610 orang. Kota Medan memiliki potensi pertumbuhan perekonomian yang sangat pesat, Badan Pusat Statistik (BPS) kota Medan mencatat ekonomi kota Medan tahun 2018 tumbuh sebesar 5,92\%. Meskipun potensi usaha mikro sangat potensial, tapi berbagai persoalan masih terus melilit usaha mikro, sehingga menjadikannya sulit berkembang. Sebagai pondasi ekonomi, sektor UMKM adalah sektor yang paling pertama terdampak wabah Covid-19 karena ketiadaan kegiatan di luar rumah oleh sebagian besar masyarakat. Penelitian ini bermaksud untuk mengetahui dan menganalisis masalah - masalah yang di hadapi Usaha Kecil Menengah serta strategi penguatannya pada masa Pandemi Covid 19 di Kota Medan. Penelitian ini merupakan penelitian kualitatif dengan telaah literature yang dilaksanakan di kota Medan pada bulan Juli -November 2020. Jenis data yang digunakan adalah data sekunder dari Badan Pusat Statistik dan Kementerian Koperasi dan Usaha Kecil Menengah dengan objek penelitian adalah pelaku UMKM. Hasil penelitian menunjukkan bahwa penjualan produk UMKM di kota Medan mengalami penurunan sebesar $68 \%$ diakibatkan sulitnya mendapatkan bahan baku dan terhambatnya proses distribusi serta kesulitan dalam permodalan yang berdampak pada melambatnya proses produksi sebesar 16\% dari jumlah keseluruhan UMKM di kota Medan. Adapun strategi penguatannya yaitu strategi Rapid Skimming dengan menetapkan harga penjualan dan promosi yang tinggi, atau sebaliknya yaitu strategi Low Skimming, dan strategi Rapid Penetration, dengan menetapkan harga produk yang rendah dan promosi yang tinggi atau sebaliknya dengan strategi Slow Penetration.
\end{abstract}

Kata kunci: Strategi Penguatan; UMKM; Pandemi Covid-19

\begin{abstract}
It cannot be denied that micro, small and medium enterprises have a strategic role in the country's economic system, among these strategic roles are absorbing local resources and wider employment opportunities and contributing to efforts to alleviate poverty. Based on data from the Ministry of Cooperatives and SMEs of the Republic of Indonesia in 2017, the workforce absorbed from MSMEs was 97.02\%. This figure increased from the previous year of 112,828,610 people. The city of Medan has the potential for very rapid economic growth, the Central Statistics Agency (BPS) of Medan noted that the economy of Medan in 2018 grew by 5.92\%. Even though the potential of micro-businesses is very potential, various problems still surround microbusinesses, making it difficult to develop. As an economic foundation, the MSME sector is the sector most affected by the Covid19 outbreak due to the absence of activities outside the home by most people. This study intends to identify and analyze the problems faced by Small and Medium Enterprises and strategies for their strengthening during the Covid 19 Pandemic in Medan City. This research is a qualitative study with a literature review which was conducted in the city of Medan in July-November 2020. The type of data used is secondary data from the Central Statistics Agency and the Ministry of Cooperatives and Small and Medium Enterprises with the object of research being MSME actors. The results showed that the sales of MSME products in the city of Medan decreased by 68\% due to difficulty in obtaining raw materials and delays in the distribution process as well as difficulties in capital which resulted in a slowing down of the production process by $16 \%$ of the total number of MSMEs in the city of Medan. The strengthening strategy is the Rapid Skimming strategy by setting high sales and promotion prices, or vice versa, namely the Low Skimming strategy and the Rapid Penetration strategy, by setting low product prices and high promotions or vice versa with the Slow Penetration strategy.
\end{abstract}

Keywords: Strengthening Strategies; MSMEs; Pandemic Covid-19

\section{PENDAHULUAN}

Tidak dapat di pungkiri bahwa usaha mikro kecil menengah memiliki peran yang strategis dalam sistem ekonomi Negara. Diantara peran strategis tersebut adalah menyerap lapangan kerja yang lebih luas, menyerap sumber daya lokal sehingga memberi penghasilan yang berdampak positif pada upaya pengentasan kemiskinan.

Berdasarkan data Kementerian Koperasi dan UKM Republik Indonesia pada tahun 2017 tenaga kerja yang terserap dari usaha mikro, kecil, dan menengah sebanyak 116.673.416 juta orang atau 97,02\%. Angka ini meningkat dari tahun sebelumnya sebanyak 112.828.610 juta orang. Rinciannya, usaha mikro sebanyak 107.232.992 juta orang atau 89,17\%, usaha kecil sebanyak 5.704.321 juta orang atau 4,74\%, dan usaha menengah 3.736 .103 juta orang atau $3,11 \%$ (www.depkop.go.id, 2017). 
Secara sederhana usaha mikro kecil menengah didefenisikan sebagai usaha produktif yang dijalankan oleh perseorangan ataupun sebuah badan usaha bukan berupa anak maupun cabang perusahaan yang dikuasai secara langsung maupun tidak langsung oleh usaha besar yang pendiriannya secara mandiri dengan memenuhi kriteria sebagai usaha menengah seperti memiliki kekayaan bersih antara lima ratus juta rupiah sampai sepuluh miliar rupiah atau memperoleh hasil produksi antara Rp.2,5 miliar sampai Rp.50 miliar. (Kuncoro, 2010). Selain itu, usaha mikro kecil menengah ini juga merupakan bentuk usaha yang menggunakan teknologi sederhana dengan pemodalan yang relatif kecil karena tidak ada pemisahan antara modal usaha dengan pembiayaan kebutuhan probadi para pelaku usahanya (Husaeni \& Dewi, 2019).

Keunggulan usaha mikro kecil menengah umumnya dalam bidang memanfaatkan sumber daya alam lokal dan padat karya, seperti : pertanian, perkebunan, peternakan, perikanan, perdagangan. Dengan kata lain, usaha mikro bergerak pada sektor riil, yaitu sektor yang umumnya digerakkan oleh masyarakat menengah ke bawah.

Peran masyarakat dalam pembangunan nasional, utamanya dalam pembangunan ekonomi adalah Usaha Mikro, Kecil, dan Menengah. Posisi Usaha Mikro, Kecil, dan Menengah (UMKM) dalam perekonomian nasional memiliki peran yang penting dan strategis. Kondisi tersebut sangat memungkinkan karena eksistensi UMKM cukup dominan dalam perekonomian Indonesia, dengan alasan jumlah industri yang besar dan terdapat dalam setiap sektor ekonomi; potensi yang besar dalam penyerapan tenaga kerja, dan kontribusi UMKM dalam pembentukan Produk Domestik Bruto (PDB) sangat dominan (Fidela, Pratama, \& Nursyamsiah, 2020).

Kota Medan sebagai kota terbesar ketiga di Indonesia, memiliki potensi pertumbuhan perekonomian yang sangat pesat, Badan Pusat Statistik (BPS) kota Medan mencatat Ekonomi Kota Medan Tahun 2018 tumbuh sebesar 5,92\%. Tiga Lapangan usaha yang member peran dominan terhadap PDRB Kota Medan pada tahun 2018 yaitu Perdagangan besar dan eceran dan reparasi mobil dans epeda motor sebesar 24,96\%, konstruksi sebesar $19,32 \%$, serta industri pengolahan sebesar $14,61 \%$. Dari data tersebut dapat dilihat bahwa kontribusi usaha mikro kecil menengah sangat besar di kota Medan.

Meskipun potensi usaha mikro sangat potensial, tapi berbagai persoalan masih dan terus melilit usaha mikro, sehingga menjadikan usaha mikro sulit berkembang. Problematika usaha mikro sangat beragam dan kompleks, secara garis besar dapat dibagi kepada dua bagian yaitu persoalan internal dan eksternal. Persoalan internal usaha mikro yang harus diperbaiki mencakup beberapa aspek yaitu : aspek kekuatan permodalan, kualitas SDM terutama jiwa kewirausahaan (entrepreneuship), penguasaan pemanfaatan teknologi dan informasi, struktur organisasi, sistem manajemen, kultur/budaya bisnis, dan jaringan bisnis dengan pihak luar (Apriliana, 2019).

Sedangkan persoalan eksternal adalah yang terkait dengan kebijakan pemerintah, aspek hukum, kondisi persaingan pasar, kondisi ekonomi-sosialkemasyarakatan, kondisi infrastruktur, tingkat pendidikan masyarakat, dan perubahan ekonomi global. Di samping persoalan internal dan eksternal, usaha mikro juga masih menghadapi berbagai persoalan yang terkait dengan iklim usaha seperti ; besarnya biaya transaksi, biaya perizinan, panjangnya proses perizinan, timbulnya berbagai pungutan liar dan praktik usaha yang tidak sehat.

Selain dari kedua masalah tersebut, saat ini terdapat masalah yang lebih serius di hadapi oleh usaha mikro kecil menengah yaitu mewabahnya virus Corona (Covid-19) yang melanda beberapa Negara termasuk Negara Indonesia dan bahkan hampir seluruh kota di Indonesia termasuk kota Medan, sangat dirasakan dampaknya oleh pelaku usaha mikro kecil menengah terkait dengan daya beli masyarakat yang turun drastis sehingga mempengaruhi jumlah produksi, penjualan dan keuntungan yang di peroleh (Amri, 2020).

Mengutip informasi dari kompas.com, pemerintah Indonesia pertama kalinya mengumumkan dua kasus pasien positif covid-19 pada 2 Maret 2020, dan terus bertambah kasus pasien yang positif sampai saat ini. Sehingga berdampak pada aktivitas ekonomi, dan dampak yang paling besar dialami oleh usaha mikro kecil menengah.

Sebagai pondasi ekonomi sektor UMKM adalah sektor yang paling pertama terdampak wabah covid-19 karena ketiadaan kegiatan di luar rumah oleh sebagian besar masyarakat, dengan mengurangi aktivitas di luar rumah disebut dengan istilah Lock Down. Kondisi tersebut diperparah dengan kendala impor bahan baku dan barang modal.

Oleh sebab aktivitas masyarakat terbatas, maka kenaikan harga barang ditambah penghasilan yang menurun adalah kombinasi fatal pemukul daya beli. Walaupun pemerintah mengeluarkan kebijakan membebaskan pembayaran bunga dan penundaan pokok angsuran KUR untuk usaha yang terkena dampak Covid19, namun pelaku usaha mikro kecil menengah tidak cukup hanya pasrah saja dengan keadaan, yang justru akan menjadikannya terpuruk.

Oleh sebab itu dibutuhkan langkah-langkah strategis dalam penguatan usaha mikro kecil menengah dalam menghadapi dampak virus corona (Covid-19) guna meningkatkan daya beli masyarakat.

\section{METODE}

Penelitian ini merupakan penelitian kualitatif dengan telaah literature, adapun tahapan-tahapan penelitian yang penulis lakukan dalam penelitian ini dengan menentukan topik dan ide penelitian, dilanjutkan 
dengan menentukan lokasi dan jadwal penelitian, menentukan jenis dan sumber data, metode analisis data. Penelitian ini dilaksanakan di kota Medan pada bulan Juli -November 2020. Jenis data yang digunakan adalah data sekunder dari Badan Pusat Statistik melalui situs resminya yaitu http://medankota.bps.go.id dan Kementerian Koperasi dan Usaha Kecil Menengah melalui situs resmi http://depko.go.id dengan objek penelitian adalah pelaku UMKM. Metode analisis data menggunakan analisis deskriptif. Proses telaah data dimulai dengan identifikasi perkembangan UMKM dan permasalahannya, kemudian dilanjutkan dengan penelusuran data dan menyajikannya secara naratif sehingga dapat ditarik kesimpulan.

\section{HASIL DAN PEMBAHASAN \\ Kota Medan: Gambaran Geografis dan Administratif Wilayah}

Kondisi umum Kota Medan ditinjau dari kepentingan ekonomi memberikan keuntungan kompetitif, karena relatif datar dalam hamparan yang sangat luas dan merupakan kota pelabuhan di Selat Malaka. Hal ini terlihat dari perkembangan dan pertumbuhan ekonomi Kota Medan yang selalu berada diatas rata-rata pertumbuhan ekonomi provinsi dan nasional.

Luas wilayah administrasi Kota Medan adalah seluas 26.510 Ha yang terdiri dari 21 (dua puluh satu) Kecamatan dengan 151 kelurahan yang terbagi dalam 2.000 lingkungan. Kecamatan Medan Labuhan memiliki

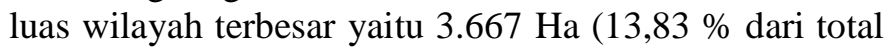
wilayah Kota Medan). Kecamatan Medan Belawan merupakan daerah yang memiliki luas terbesar kedua yaitu sekitar 2.625 Ha. Sedangkan Kecamatan Medan Maimun memiliki luas wilayah terkecil yaitu $298 \mathrm{Ha}$ (1,12\% dari total luas keseluruhan).

Tabel 1. Luas Wilayah Kota Medan Menurut Kecamatan

\begin{tabular}{|c|c|c|c|c|c|}
\hline No & Kecamatan & Luas Area $\left(\mathrm{Km}^{2}\right)$ & Persentase (\%) & Kelurahan & Lingkungan \\
\hline 1 & Medan Tuntungan & 20,68 & 7,80 & 9 & 75 \\
\hline 2 & Medan Johor & 14,58 & 5,50 & 6 & 81 \\
\hline 3 & Medan Amplas & 11,19 & 4,22 & 7 & 77 \\
\hline 4 & Medan Denai & 9,05 & 3,41 & 6 & 82 \\
\hline 5 & Medan Area & 5,52 & 2,08 & 12 & 172 \\
\hline 6 & Medan Kota & 5,27 & 1,99 & 12 & 146 \\
\hline 7 & Medan Maimun & 2,98 & 1,12 & 6 & 66 \\
\hline 8 & Medan Polonia & 9,01 & 3,40 & 5 & 46 \\
\hline 9 & Medan Baru & 5,84 & 2,20 & 6 & 64 \\
\hline 10 & Medan Selayang & 12,81 & 4,83 & 6 & 63 \\
\hline 11 & Medan Sunggal & 15,44 & 5,82 & 6 & 88 \\
\hline 12 & Medan Helvetia & 13,16 & 4,96 & 7 & 88 \\
\hline 13 & Medan Petisah & 6,82 & 2,57 & 7 & 69 \\
\hline 14 & Medan Barat & 5,33 & 2,01 & 6 & 98 \\
\hline 15 & Medan Timur & 7,76 & 2,93 & 11 & 128 \\
\hline 16 & Medan Perjuangan & 4,09 & 1,54 & 9 & 128 \\
\hline 17 & Medan Tembung & 7,99 & 3,01 & 7 & 96 \\
\hline 18 & Medan Deli & 20,84 & 7,86 & 6 & 105 \\
\hline 19 & Medan Labuhan & 36,67 & 13,83 & 6 & 99 \\
\hline 20 & Medan Marelan & 23,82 & 8,99 & 5 & 88 \\
\hline \multirow[t]{2}{*}{21} & Medan Belawan & 26,25 & 9,90 & 6 & 143 \\
\hline & Jumlah & 265,10 & 100,00 & 151 & 2.001 \\
\hline
\end{tabular}

\section{Usaha Mikro Kecil Menengah di Kota Medan}

Usaha Mikro, Kecil dan Menengah (UMKM) tetap bertahan dan sangat berkontribusi terhadap Pembangunan Ekonomi di Indonesia. Dalam mewujudkan kemakmuran, kumpulan kelembagaan pengusaha diharapkan akan meningkatkan strategi yang bisa menyelesaikan segala permasalahan UMKM dan beberapa dari anggota yang terhimpun juga bisa memberikan saran dan kritik membangun untuk bisa menjadikan konsep bisnis bisa menjadi lebih bagus dan pertemuan yang dilaksanakan bertajuk mentoring, seminar hingga gathering, bisa mempertemukan dari semua kalangan di Kota Medan baik dari pemerintah Kota Medan, Akademisi, Komunitas Bisnis dan masyarakat umum untuk bisa menciptakan semangat pembaharu (cracker) yang tentunya bisa menjadi kontribusi penting terhadap pembangunan ekonomi di Kota Medan.

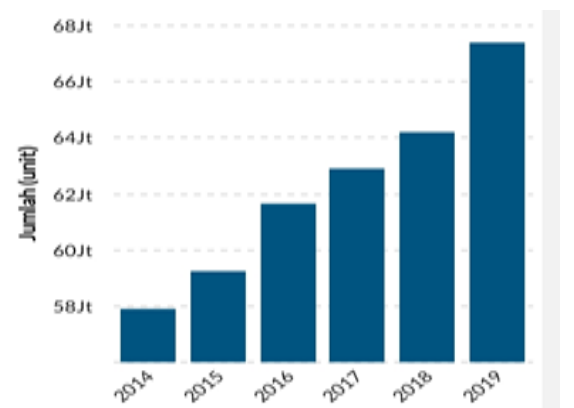

Gambar 1. Jumlah UMKM Kota Medan Tahun 2014-2019

Berdasarkan gambar di atas, menunjukkan pertumbuhan dan perkembangan UMKM terus meningkat selama lima tahun terakhir. Ini membuktikan bahwa UMKM sebagai penopang perekonomian yang kokoh sehingga membutuhkan perhatian yang sangat penting baik bagi pemerintah maupun pelaku usaha.

Sesuai dengan hasil penelitian menunjukkan bahwa Usaha Mikro, Kecil, dan Menengah (UMKM) menjadi salah satu sub-sektor yang harus mendapat perhatian karena peran sentral dalam menopang perekonomian di Indonesia. Sekitar 90\% tenaga kerja terserap pada sektor ini dan kontribusinya terhadap PDB sebesar 60\%. Jika dirupiahkan kontribusi UMKM terhadap perekonomian nasional Indonesia di tahun 2018 dapat dikatakan cukup besar dengan nilai sebesar $\mathrm{Rp}$ 8.400 Triliun.

Masalah-masalah yang di hadapi Usaha Kecil Menengah pada masa Pandemi Covid 19 di Kota Medan

Kepala Dinas Perindustrian dan Perdagangan (Disperindag) Sumut Riadil Akhir Lubis menyatakan. Masalah yang dihadapi pelaku bisnis UMKM pada masa pandemi Virus Corona di antaranya adalah:

1. Mengalami Penurunan Penjualan

Sejak terjadinya wabah Corona, tentu saja hal ini berdampak pada daya beli dari masyarakat itu sendiri.Hal inilah yang membuat penjualan UMKM mengalami penurunan.Sebanyak 774 koperasi dan UMKM atau setara dengan 68\% mengaku bahwa 
penjualan mereka mengalami penurunan drastis sejak wabah Virus Corona.

2. Sulit Mendapatkan Bahan Baku

Selain mengalami penurunan penjualan, para pelaku UMKM tersebut juga mengaku kesulitan mendapatkan bahan baku karena kegiatan impor yang dibatasi. Tercatat, ada sekitar 63 koperasi dan UMKM (6\%) mengeluhkan kesulitan bahan baku.

3. Terhambatnya Distribusi

Sebanyak 111 koperasi serta UMKM (setara 10 persen) mengungkapkan bahwa distribusi yang mereka lakukan menjadi terhambat, terlebih saat sudah ada penerapan social dintancing di wilayah masing-masing.Tentu saja hal ini membuat pengiriman atau penerimaan barang kepada konsumen menjadi terlambat.

4. Mengalami Kesulitan Permodalan

Tercatat, sebanyak 141 koperasi dan UMKM (12 persen) mengeluhkan bahwa mereka mengalami masalah permodalan.

5. Terhambatnya Produksi

Sebanyak 42 koperasi serta UMKM (4 persen) mengungkapkan bahwa produksi mereka menjadi terhambat dengan adanya wabah Virus Corona (Covid-19) seperti sekarang ini, salah satunya adalah kesulitan mendapatkan bahan baku.

\section{Solusi yang dilakukan dalam Penguatan Usaha Kecil Menengah pada masa Pandemi Covid 19 di Kota Medan}

Solusi yang yang ditawarkan adalah:

1. Penyediaan modal dan akses kepada sumber dan lembaga keuangan. Ditambah dengan pemberian kemudahan (bukan berbelit-belit) dalam mengurus administrasi untuk mendapatkan modal dari lembaga keuangan. Dapat juga melalui pengefektifan dan pengefisienan program Kredit Usaha Rakyat (KUR) yang telah disediakan oleh pemerintah.

2. Meningkatkan kualitas dan kapasitas kompetensi SDM. Melalui pendidikan dan pelatihan baik dilakukan oleh pemerintah maupun oleh koperasi atau UMKM itu sendiri. Meningkatkan kemampuan pemasaran UMKM. Pemberian pendidikan mengenai pemasaran atau dengan cara membuka/merekrut tenaga profesional yang ahli dalam halpemasaran.

3. Meningkatkan akses informasi usaha bagi UMKM.

4. Menjalin kemitraan yang saling menguntungkan antar pelaku usaha (UMKM, Usaha Besar danBUMN).

5. Melakukan/membuat program goes to goal, yaitu langsung ke tujuan atau sasaran. Dilakukan dengan cara memberikan bantuan baik modal, konsep, dan hal-hal yang dibutuhkan oleh koperasi dan UMKM atau dengan membidik para individu yang memiliki jiwa enterpreneur dengan tetap adanya prinsip prudensial dan adanya manager investasi (meminjam istilah perbankan syariah dimana nasabah yang telah diberi pinjaman tetap terus mendapat pengawasan atau layanan prima dalam pengolahan dana yang).

\section{Strategi Penguatan Usaha Kecil Menengah pada masa Pandemi Covid 19 di Kota Medan}

Assauri (2014), menjelaskan, strategi penetrasi pasar, memungkinkan untuk UMKM mengetahui setiap kekuatan yang timbul di dalam perusahaanya dan dibandingkan dengan perusahaan lain. Sisi kelemahan yang ditemua, perlu dilakukan evaluasi secara terus menerus. beberapa strategi penetrasi pasar yang dapat digunakan terkait dalam usaha untuk meningkatkan pengusahaan pasar oleh perusahaan dan sekaligus meningkatkan penjualan adalah:

1. Strategi Rapid Skimming

Strategi ini dijalankan dengan menetapkan tingkat harga penjualan dan tingkat kegiatan promosi yang lebih tinggi. Strategi rapid skimming hanya dapat dilaksanakan dengan menggunakan beberapa asumsi sebagai berikut:

a. Sebagian besar potensi pasar yang belum mengenalproduk.

b. Calon konsumen yang telah mengenal produk akan tertarik untuk memiliki produk tersebut dan memiliki kesanggupan untuk membayar harga yangdiminta.

c. Perusahaan menghadapi persaingan yang potensial dan bertujuan untuk membangun preferensi merek (brandpreference).

2. Strategi Low Skimming

Strategi ini dijalankan dengan menetapkan harga penjualan yang tinggi dan kegiatan promosi yang rendah. Tujuan penetapan harga jual yang tinggi adalah memperoleh laba per unit setinggi-tingginya, sebelum para pesaing memasuki pasar dengan menawarkan pruk yang sama. Strategi Low Skimming hanya dapat dilaksanakan dengan menggunakan beberapa asumsi sebagai berikut:

a. Luas pasar secara relative terbatas.

b. Sebagian besar pasar telah mengenal produkitu.

c. Calon konsumen bersedia membayar harga yang diminta

\section{Strategi Rapid Penetration}

Strategi ini dijalankan dengan menetapkan harga produk yang rendah dan kegiatan promosi yang tinggi. Strategi ini dijalankan dengan tujuan agar perusahaan dapat menyusup di pasar dan dapat memasuki pasar secepat-cepatnya, sehingga dapat diperoleh share pasar sebesar- besarnya. Strategi rapid penetration hanya dapat dijalankan dengan menggunakan beberapa asumsi sebagai berikut:

a. Luas pasar relatif cukupbesar

b. Umumnya pasar itu belum mengenal produk

c. Calon konsumen umumnya peka terhadap harga

d. Kemungkinan ancaman para pesaing cukup besar, dan 
e. Biaya produksi per unit cenderung menurun dengan bertambahnya jumlah produksi dan pengalamankerja.

4. Strategi Slow Penetration

Strategi ini dijalankan dengan menetapkan harga jual yang rendah dan kegiatan promosi yang rendah juga. Harga yang rendahd imaksudkan agar perusahaan dapat merangsang pasar untuk menyerap produk dengan cepat, sedangkan di lain pihak, perusahaan dapat menjaga agar biaya promosinya tetap rendah,sehingga laba bersih yang dapat diperoleh cukupb esar.Dengan strategi ini, perusahaan beranggapan pasar tersebut mempunyai harga yang cukup elastis, tetapi promosinya kurang elastis. Strategi slow penetration hanya dapat dijalankan dengan menggunakan beberapa asumsi sebagai berikut:

a. Luas pasar relatif cukup besar.

b. Umumnya pasar itu sangat mengenal produk tersebut

c. Umumnya pasar out sangat sensitive terhadap harga (pricesensitive)

d. Kemungkinan ada ancaman dari parapesaing.

\section{SIMPULAN}

Adapun kesimpulan dalam penelitian ini adalah sebagai berikut:

1. Masalah yang dihadapi Usaha Kecil Menengah pada mas apandemi Covid 19 sebagai berikut

a. Mengalami Penurunan Penjualan sebesar 68\%

b. Sulit Mendapatkan Bahan Baku. Tercatat ada sekitar (6\%) mengeluhkan kesulitan bahan baku.

c. Terhambatnya Distribusi. Sebanyak 111 koperasi serta UMKM (setara 10 persen) mengungkapkan bahwa distribusi yang mereka lakukan menjadit erhambat

d. Mengalami Kesulitan Permodalan. Tercatat, sebanyak 141 koperasidan UMKM (12 persen)

e. Terhambatnya Produksi. Sebanyak 42 koperasi serta UMKM (4 persen).

2. Solusi yang dilakukan dalam Penguatan Usaha Kecil Menengah pada masa PandemiCovid 19 di Kota Medan

a. Penyediaan modal dan akses kepada sumber dan lembaga keuangan.

b. Meningkatkan kualitas dan kapasitas kompetensi SDM.

c. Meningkatkan akses informasi usaha bagi UMKM.

d. Menjalin kemitraan yang saling menguntungkan antar pelaku usaha (UMKM, Usaha Besar dan BUMN).

e. Melakukan/membuat program goes to goal, yaitu langsung ke tujuan atau sasaran.

3. Strategi Penguatan Usaha Kecil Menengah pada masa PandemiC ovid 19 di Kota Medan

a. Strategi Rapid Skimming, menetapkan tingkat harga penjualan dan tingkat kegiatan promosi yang lebih tinggi.

b. Strategi Low Skimming, menetapkan harga penjualan yang tinggi dan kegiatan promosi yang rendah.

c. Strategi Rapid Penetration, menetapkan harga produk yang rendah dan kegiatan promosi yang tinggi.

d. Strategi Slow Penetration, menetapkan hargaj ual yang rendah dan kegiatan promosi yang rendah juga.

\section{DAFTAR PUSTAKA}

Amri, A. (2020). Dampak Covid-19 Terhadap UMKM di Indonesia. Jurnal Brand, 2(1), 123-130. Retrieved from https://www.academia.edu/42672824/Dampak_Co vid-19_Terhadap_UMKM_di_Indonesia

Apriliana, E. D. (2019). Strategi Pengembangan Umkm Batik Untuk Meningkatkan Daya Saing Batik Semarangan Di Kampung Batik Kota Semarang. Retrieved from https://lib.unnes.ac.id/35755/

Assauri, S. (2014). Manajemen Pemasaran Dasar, Konsepdan Strategi. Jakarta: Raja Grafindo Persada.

Fidela, A., Pratama, A., \& Nursyamsiah, T. (2020). Pengembangan Usaha Mikro Kecil dan Menengah ( UMKM ) dengan Program Pemasaran Desa Jambu Raya di Desa Jambu , Kabupaten Sumedang Development Of Micro Small and Medium Enterprises ( Smes ) With The Marketing Program Of Guava Village In Jambu Village , Sume. Jurnal Pusat Inovasi Masyarakat, 2(3), 493-498.

Husaeni, U. A., \& Dewi, T. K. (2019). Pengaruh Pembiayaan Mikro Syariah Terhadap Tingkat Perkembangan Usaha Mikro Kecil Menengah (Umkm) Pada Anggota Bmt Di Jawa Barat. Bongaya Journal for Research in Management (BJRM), 2(1), 48-56. https://doi.org/10.37888/bjrm.v2i1.122

Kuncoro, Mudrajat. (2010). Masalah, Kebijakan, dan Politik Ekonomika Pembangunan. Jakarta. Penerbit: Erlangga.

http://www.depkop.go.id/uploads/tx_rtgfiles/SANDINGAND ATAUMKM20122017.pdf di akses pada, 10-Juli-2020, pukul 20.45 wib

https://www.kompas.com/sains/read/2020/05/11/130600623/d iumumkan-awal-maret-ahli-virus-corona-masukindonesia-dari-januari. Diakses pada Selasa, 14-072020. 08.30 Wib

https://medankota.bps.go.id/pressrelease/2019/07/16/70/pertu mbuhan-ekonomi-kota-

medantahun2018.html\#: :text=Ekonomi\%20Kota\%20 Medan\%20Tahun\%202018\%20tumbuh\%20sebesar\%2 05\%2C92\%25.,pengolahan\%20sebesar\%2014\%2C61 \%25. Diakses pada, 15-Juli-2020. Pukul 09.30 wib 